\title{
Regulation of inorganic carbon acquisition in a red tide alga (Skeletonema costatum): the importance of phosphorus availability
}

\author{
Guang Gao ${ }^{1,2,3}$, Jianrong Xia ${ }^{1}$, Jinlan $\mathrm{Yu}^{1}$, Jiale Fan ${ }^{2}$, and Xiaopeng Zeng ${ }^{1}$ \\ ${ }^{1}$ School of Environmental Science and Engineering, Guangzhou University, Guangzhou, 510006, China \\ ${ }^{2}$ Jiangsu Key Laboratory of Marine Bioresources and Environment, Huaihai Institute of Technology, \\ Lianyungang, 222005, China \\ ${ }^{3}$ State Key Laboratory of Marine Environmental Science, Xiamen University, Xiamen, 361005, China
}

Correspondence: Jianrong Xia (jrxia@gzhu.edu.cn)

Received: 6 November 2017 - Discussion started: 29 November 2017

Revised: 18 July 2018 - Accepted: 7 August 2018 - Published: 17 August 2018

\begin{abstract}
Skeletonema costatum is a common bloomforming diatom and encounters eutrophication and severe carbon dioxide $\left(\mathrm{CO}_{2}\right)$ limitation during red tides. However, little is known regarding the role of phosphorus $(\mathrm{P})$ in modulating inorganic carbon acquisition in $S$. costatum, particularly under $\mathrm{CO}_{2}$ limitation conditions. We cultured $S$. costatum under five phosphate levels $(0.05,0.25$, $1,4,10 \mu \mathrm{mol} \mathrm{L}^{-1}$ ) and then treated it with two $\mathrm{CO}_{2}$ conditions $\left(2.8\right.$ and $\left.12.6 \mu \mathrm{mol} \mathrm{L}^{-1}\right)$ for $2 \mathrm{~h}$. The lower $\mathrm{CO}_{2}$ reduced net photosynthetic rate at lower phosphate levels $\left(<4 \mu \mathrm{mol} \mathrm{L}^{-1}\right)$ but did not affect it at higher phosphate levels $\left(4\right.$ and $\left.10 \mu \mathrm{mol} \mathrm{L}^{-1}\right)$. In contrast, the lower $\mathrm{CO}_{2}$ induced a higher dark respiration rate at lower phosphate levels $\left(0.05\right.$ and $\left.0.25 \mu \mathrm{mol} \mathrm{L}^{-1}\right)$ and did not affect it at higher phosphate levels $(>1 \mu \mathrm{mol} \mathrm{L}-1)$. The lower $\mathrm{CO}_{2}$ did not change relative electron transport rate (rETR) at lower phosphate levels $\left(0.05\right.$ and $\left.0.25 \mu \mathrm{mol} \mathrm{L}^{-1}\right)$ and increased it at higher phosphate levels $\left(>1 \mu \mathrm{mol} \mathrm{L}^{-1}\right)$. Photosynthetic $\mathrm{CO}_{2}$ affinity $\left(1 / K_{0.5}\right)$ increased with phosphate levels. The lower $\mathrm{CO}_{2}$ did not affect photosynthetic $\mathrm{CO}_{2}$ affinity at $0.05 \mu \mathrm{mol} \mathrm{L}{ }^{-1}$ phosphate but enhanced it at the other phosphate levels. Activity of extracellular carbonic anhydrase was dramatically induced by the lower $\mathrm{CO}_{2}$ in phosphate-replete conditions $\left(>0.25 \mu \mathrm{mol} \mathrm{L}^{-1}\right)$ and the same pattern also occurred for redox activity of the plasma membrane. Direct bicarbonate $\left(\mathrm{HCO}_{3}^{-}\right)$use was induced when phosphate concentration was more than $1 \mu \mathrm{mol} \mathrm{L}-1$. These findings indicate $P$ enrichment could enhance inorganic carbon acquisition and thus maintain the photosynthesis rate in $S$. costatum grown under $\mathrm{CO}_{2}$-limiting conditions via increasing activity of ex-
\end{abstract}

tracellular carbonic anhydrase and facilitating direct $\mathrm{HCO}_{3}^{-}$ use. This study sheds light on how bloom-forming algae cope with carbon limitation during the development of red tides.

\section{Introduction}

Diatoms are unicellular photosynthetic microalgae that can be found worldwide in freshwater and oceans. Marine diatoms account for $75 \%$ of the primary productivity for coastal and other nutrient-rich zones and approximately $20 \%$ of global primary production (Field et al., 1998; Falkowski, 2012), hence playing a vital role in the marine biological carbon pump as well as the biogeochemical cycling of important nutrients, such as nitrogen and silicon (Nelson et al., 1995; Moore et al., 2013; Young and Morel, 2015). Diatoms usually dominate the phytoplankton communities and form large-scale blooms in nutrient-rich zones and upwelling regions (Bruland et al., 2001; Anderson et al., 2008; Barton et al., 2016). Nutrient enrichment is considered to be a key factor that triggers algal blooms, albeit the occurrence of diatom blooms may be modulated by other environmental factors, such as temperature, light intensity, and salinity (Smetacek and Zingone, 2013; Jeong et al., 2015). When inorganic nitrogen and phosphorus are replete, diatoms can outcompete chrysophytes, raphidophytes, and dinoflagellates (Berg et al., 1997; Jeong et al., 2015; Barton et al., 2016) and dominate algal blooms due to their quicker nutrient uptake and growth rate. 
In normal natural seawater ( $\mathrm{pH} 8.1$, salinity 35$), \mathrm{HCO}_{3}^{-}$ is the majority $(\sim 90 \%)$ of total dissolved inorganic carbon (DIC, $2.0-2.2 \mathrm{mM}) . \mathrm{CO}_{2}(1 \%, 10-15 \mu \mathrm{M})$, which is the only direct carbon source that can be assimilated by all photosynthetic organisms, only accounts for $1 \%$ of total DIC. Diatoms' ribulose-1,5-bisphosphate carboxylase/oxygenase (Rubisco), catalyzing the primary chemical reaction by which $\mathrm{CO}_{2}$ is transformed into organic carbon, has a relatively low affinity for $\mathrm{CO}_{2}$ and is commonly less than half saturated under current $\mathrm{CO}_{2}$ levels in seawater (Hopkinson and Morel, 2011), suggesting that $\mathrm{CO}_{2}$ is limiting for marine diatoms' carbon fixation. To cope with the $\mathrm{CO}_{2}$ limitation in seawater and maintain a high carbon fixation rate under the low- $\mathrm{CO}_{2}$ conditions, diatoms have evolved various inorganic carbon acquisition pathways and $\mathrm{CO}_{2}$ concentrating mechanisms (CCMs), for instance, active transport of $\mathrm{HCO}_{3}^{-}$, the passive influx of $\mathrm{CO}_{2}$, multiple carbonic anhydrase (including both common $(\alpha, \beta, \gamma$, found in all algae) and unusual ( $\delta, \zeta$, found only in diatoms) families that carry out the fast interconversion of $\mathrm{CO}_{2}$ and $\mathrm{HCO}_{3}^{-}$), and assumed C4-type pathway (using phosphoenolpyruvate to capture more $\mathrm{CO}_{2}$ in the periplastidal compartment), to increase the concentration at the location of Rubisco and thus the carbon fixation (Hopkinson and Morel, 2011; Hopkinson et al., 2016). Skeletonema costatum is a worldwide diatom species that can be found from equatorial to polar waters. It usually dominates large-scale algal blooms in eutrophic seawaters (Wang, 2002; $\mathrm{Li}$ et al., 2011). When blooms occur, seawater $\mathrm{pH}$ increases and $\mathrm{CO}_{2}$ decreases because the dissolution rate of $\mathrm{CO}_{2}$ from the atmosphere cannot catch up with its removal rate caused by intensive photosynthesis of algae. For instance, $\mathrm{pH}$ level in the surface waters of the eutrophic Mariager Fjord, Denmark, could be up to 9.75 during algal blooms (Hansen, 2002). Consequently, $S$. costatum experiences very severe $\mathrm{CO}_{2}$ limitation when blooms occur. To deal with it, $S$. costatum has developed multiple CCMs (Nimer et al., 1998; Rost et al., 2003). However, contrasting findings were reported. Nimer et al. (1998) documented that extracellular carbonic anhydrase activity in $S$. costatum was only induced when $\mathrm{CO}_{2}$ concentration was less than $5 \mu \mathrm{mol} \mathrm{L}^{-1}$ while Rost et al. (2003) reported that activity of extracellular carbonic anhydrase could be detected even when $\mathrm{CO}_{2}$ concentration was $27 \mu \mathrm{mol} \mathrm{L}^{-1}$. Chen and Gao (2004) showed that S. costatum had little capacity in direct $\mathrm{HCO}_{3}^{-}$utilization. Conversely, Rost et al. (2003) demonstrated that this species could take up $\mathrm{CO}_{2}$ and $\mathrm{HCO}_{3}^{-}$simultaneously.

Phosphorus $(\mathrm{P})$ is an indispensable element for all living organisms, serving as an integral component of lipids, nucleic acids, adenosine triphosphate (ATP), and a diverse range of other metabolites. Levels of bioavailable phosphorus are very low in many ocean environments and phosphorus enrichment can commonly increase algal growth and marine primary productivity in the worldwide oceans (Davies and Sleep, 1989; Müller and Mitrovic, 2015; Lin et al., 2016). Due to the essential role of phosphorus, extensive studies have been conducted to investigate the effect of phosphorus on photosynthetic performances (Geider et al., 1998; Liu et al., 2012; Beamud et al., 2016) and growth (Jiang et al., 2016; Reed et al., 2016; Mccall et al., 2017) as well as phosphorus acquisition, utilization, and storage (Lin et al., 2016; Gao et al., 2018a). Some studies show the essential role of phosphorus in regulating inorganic carbon acquisition in green algae (Beardall et al., 2005; Hu and Zhou, 2010). In terms of $S$. costatum, studies regarding the inorganic carbon acquisition in $S$. costatum focus on its response to variation in $\mathrm{CO}_{2}$ availability. The role of phosphorus in $S$. costatum's CCMs remains unknown. Based on the connection between phosphorus and carbon metabolism in diatoms (Brembu et al., 2017), we hypothesize that phosphorus enrichment could enhance inorganic carbon utilization and hence maintain high rates of photosynthesis and growth in $S$. costatum under $\mathrm{CO}_{2}$ limitation conditions. In the present study, we aimed to test this hypothesis by investigating the variation in CCMs (including active transport of $\mathrm{HCO}_{3}^{-}$and carbonic anhydrase activity) and photosynthetic rate under five levels of phosphate and two levels of $\mathrm{CO}_{2}$ conditions. We also measured redox activity of the plasma membrane as it is deemed to be critical to activate carbonic anhydrase (Nimer et al., 1998). Our study provides helpful insights into how bloom-forming diatoms overcome $\mathrm{CO}_{2}$ limitation to maintain a quick growth rate during red tides.

\section{Materials and methods}

\subsection{Culture conditions}

Skeletonema costatum (Grev.) Cleve from Jinan University, China, was cultured in $\mathrm{f} / 2$ artificial seawater with five phosphate levels $\left(0.05,0.25,1,4,10 \mu \mathrm{mol} \mathrm{L}^{-1}\right)$ by adding different amounts of $\mathrm{NaH}_{2} \mathrm{PO}_{4} \cdot 2 \mathrm{H}_{2} \mathrm{O}$. The cultures were carried out semicontinuously at $20^{\circ} \mathrm{C}$ for 7 days. The light irradiance was set as $200 \mu \mathrm{mol}$ photons $\mathrm{m}^{-2} \mathrm{~s}^{-1}$, with a light and dark period of $12: 12$. The cultures were aerated with ambient air $\left(0.3 \mathrm{~L} \mathrm{~min}^{-1}\right)$ to maintain the $\mathrm{pH}$ at around 8.2. The cells during the exponential phase were collected and rinsed twice with DIC-free seawater that was made according to Xu et al. (2017). Afterwards, cells were resuspended in fresh media with two levels of $\mathrm{pH}(8.20$ and 8.70 , respectively corresponding to ambient $\mathrm{CO}_{2}\left(12.6 \mu \mathrm{mol} \mathrm{L}{ }^{-1}\right)$ and low $\mathrm{CO}_{2}$ $\left(2.8 \mu \mathrm{mol} \mathrm{L}^{-1}\right)$ under corresponding phosphate levels for $2 \mathrm{~h}$ before the following measurements, with a cell density of $1.0 \times 10^{6} \mathrm{~mL}^{-1}$. The concentrations of DIC were $2109 \pm 36$ and $1802 \pm 38 \mu \mathrm{mol}(\mathrm{kg} \text { seawater })^{-1}$, respectively. Cell density was determined by direct counting with an improved Neubauer hemocytometer (XB-K-25, Qiu Jing, Shanghai, China). This transfer aimed to investigate the effects of phosphate on DIC acquisition under a $\mathrm{CO}_{2}$ limitation condition. The $\mathrm{pH}$ of 8.70 was chosen considering that it is commonly used as a $\mathrm{CO}_{2}$ limitation condition (Nimer et al., 1998; Chen 
and Gao, 2004) and also occurs during algal blooms (Hansen, 2002). A total of $2 \mathrm{~h}$ should be enough to activate CCMs in S. costatum (Nimer et al., 1998). The cell density did not vary during the $2 \mathrm{~h}$ of $\mathrm{pH}$ treatment. All experiments were conducted in triplicates.

\subsection{Manipulation of seawater carbonate system}

The two levels of $\mathrm{pH}(8.20$ and 8.70$)$ were obtained by aerating the ambient air and pure nitrogen $(99.999 \%)$ until the target value and were then maintained with a buffer of $50 \mathrm{mM}$ tris (hydroxymethyl) aminomethane $\mathrm{HCl}$. The cultures were open to the ambient atmosphere and the rise of culture $\mathrm{pH}$ was due to algal photosynthesis below 0.02 units (corresponding to the decrease in $\mathrm{CO}_{2}$ less than 0.7 and $0.2 \mu \mathrm{mol} \mathrm{L}^{-1}$ for $\mathrm{pH} 8.20$ and 8.70 treatments, respectively) during the $2 \mathrm{~h}$ of $\mathrm{pH}$ treatment. $\mathrm{CO}_{2}$ level in seawater was calculated via CO2SYS (Pierrot et al., 2006) based on measured $\mathrm{pH}$ and total alkalinity (TAlk), using the equilibrium constants of $K 1$ and $K 2$ for carbonic acid dissociation (Roy et al., 1993) and the $\mathrm{KSO}_{4}^{-}$dissociation constant from Dickson (1990).

The $\mathrm{pH}_{\mathrm{NBS}}$ was measured using a $\mathrm{pH}$ meter $(\mathrm{pH} 700$, Eutech Instruments, Singapore) that was equipped with an Orion ${ }^{\circledR}$ 8102BN Ross combination electrode (Thermo Electron, USA) and calibrated with standard National Bureau of Standards (NBS) buffers $(\mathrm{pH}=4.01,7.00$, and 10.01 at $25.0^{\circ} \mathrm{C}$; Thermo Fisher Scientific Inc., USA). TAlk was determined at $25.0^{\circ} \mathrm{C}$ using Gran acidimetric titration on a $25 \mathrm{~mL}$ sample with a TAlk analyzer (AS-ALK1, Apollo SciTech, USA), using the precision $\mathrm{pH}$ meter and an Orion ${ }^{\circledR}$ 8102BN Ross electrode for detection. To ensure the accuracy of TAlk, the TAlk analyzer was regularly calibrated with certified reference materials from Andrew G. Dickson's laboratory (Scripps Institute of Oceanography, USA) at a precision of $\pm 2 \mu \mathrm{mol} \mathrm{kg}^{-1}$.

\subsection{Chlorophyll fluorescence measurement}

Chlorophyll fluorescence was measured with a pulse modulation fluorometer (PAM-2100, Walz, Germany) to assess electron transport in photosystem II (the first protein complex in the light-dependent reactions of photosynthesis) and the possible connection between electron transport and redox activity of the plasma membrane. The measured light and actinic light were 0.01 and $200 \mu \mathrm{mol}$ photons $\mathrm{m}^{-2} \mathrm{~s}^{-1}$, respectively. The saturating pulse was set to $4000 \mu \mathrm{mol}$ photons $\mathrm{m}^{-2} \mathrm{~s}^{-1}(0.8 \mathrm{~s})$. Electron transport in photosystem II (electron transport rate, ETR, $\left.\mu \mathrm{mole}^{-}(\mathrm{mg} \mathrm{Chl} a)^{-1} \mathrm{~s}^{-1}\right)=0.5 \times E \times \Phi_{\text {PSII }} \times \bar{a}^{*}$ (Dimier et al., 2009; Alderkamp et al., 2012), where $E$ ( $\mu$ mol photons $\mathrm{m}^{-2} \mathrm{~s}^{-1}$ ) is the ambient light density, $\Phi_{\mathrm{PSII}}$ (dimensionless) is the PSII photochemical efficiency and $\bar{a}^{*}$ is Chl $a$-specific absorption coefficient $\left(\mathrm{m}^{-2}(\mathrm{mg} \mathrm{Chl} a)^{-1}\right)$. Since $\bar{a}^{*}$ is light dependent, we used the value of 0.0138 based on the study of Lefebvre et al. (2007) in which the light density is very close to ours.

\subsection{Estimation of photosynthetic oxygen evolution and respiration}

The net photosynthetic and respiration rates of $S$. costatum were measured using a Clark-type oxygen electrode (YSI model 5300, USA) that was held in a circulating water bath (cooling circulator; Cole-Parmer, Chicago, IL, USA) to keep the setting temperature $\left(20^{\circ} \mathrm{C}\right)$. A total of $5 \mathrm{~mL}$ of samples was transferred to the oxygen electrode cuvette and was stirred during measurement. The light intensity and temperature were maintained the same as that in the growth condition. The illumination was provided by a halogen lamp. The increase in oxygen content in seawater within 5 min was defined as the net photosynthetic rate. To measure dark respiration rate, the samples were placed in darkness and the decrease in oxygen content within 10 min was defined as the dark respiration rate given the slower oxygen variation rate for dark respiration. Net photosynthetic rate and dark respiration rate were presented as $\mu \mathrm{mol} \mathrm{O}_{2}\left(10^{9} \text { cells }\right)^{-1} \mathrm{~h}^{-1}$.

To obtain the curve of net photosynthetic rate versus DIC, seven levels of DIC $(0,0.1,0.2,0.5,1,2$, and $4 \mathrm{mM})$ were made by adding different amounts of $\mathrm{NaHCO}_{3}$ to the Tris buffered DIC-free seawater ( $\mathrm{pH}$ 8.20). The algal samples were washed twice with DIC-free seawater before transferring to the various DIC solutions. Photosynthetic rates at different DIC levels were measured under a saturating irradiance of $400 \mu \mathrm{mol}$ photons $\mathrm{m}^{-2} \mathrm{~s}^{-1}$ and growth temperature. The algal samples were allowed to equilibrate for $2-3 \mathrm{~min}$ at each DIC level, during which a linear change in oxygen concentration was obtained and recorded. The parameter, photosynthetic half saturation constant $\left(K_{0.5}\right.$, i.e., the DIC concentration required to obtain half of the DIC-saturated maximum rate of photosynthetic $\mathrm{O}_{2}$ evolution), was calculated from the Michaelis-Menten kinetics equation (Caemmerer and Farquhar, 1981): $V=V_{\max } \times[S] /\left(K_{0.5}+[S]\right)$, where $V$ is the real-time photosynthetic rate, $V_{\max }$ is the maximum photosynthetic rate, and $[S]$ is the DIC concentration. The value of $1 / K_{0.5}$ represents photosynthetic DIC affinity. $K_{0.5}$ for $\mathrm{CO}_{2}$ was calculated via CO2SYS (Pierrot et al., 2006) based on $\mathrm{pH}$ and TAlk, using the equilibrium constants of $K 1$ and $K 2$ for carbonic acid dissociation (Roy et al., 1993) and the $\mathrm{KSO}_{4}^{-}$dissociation constant from Dickson (1990).

\subsection{Measurement of photosynthetic pigment}

To determine the photosynthetic pigment ( $\mathrm{Chl} a$ ) content, $50 \mathrm{~mL}$ of culture was filtered on a Whatman GF/ F filter, extracted in $5 \mathrm{~mL}$ of $90 \%$ acetone for $12 \mathrm{~h}$ at $4{ }^{\circ} \mathrm{C}$, and centrifuged $(3000 \mathrm{~g}, 5 \mathrm{~min})$. The optical density of the supernatant was scanned from 200 to $700 \mathrm{~nm}$ with a UV-VIS spectrophotometer (Shimadzu UV-1800, Kyoto, Japan). The concentration of Chl $a$ was calculated based on the opti- 

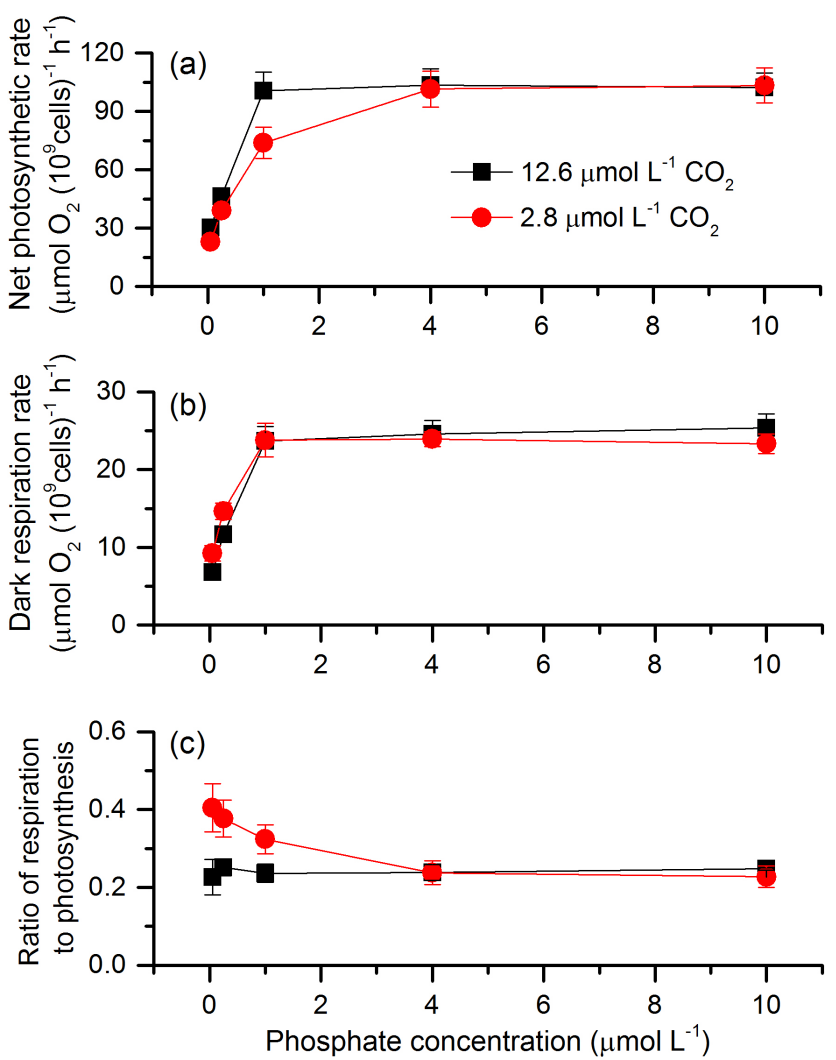

Figure 1. Net photosynthetic rate (a), dark respiration rate (b), and ratio of respiration rate to net photosynthetic rate (c) in $S$. costatum grown at various phosphate concentrations after 12.6 and $2.8 \mu \mathrm{mol} \mathrm{CO} 2$ treatments. The error bars indicate the standard deviations $(n=3)$.

cal density at 630 and $664 \mathrm{~nm}$ : Chl $a=11.47 \times \mathrm{OD}_{664}-$ $0.40 \times \mathrm{OD}_{630}$ (Gao et al., 2018b) and was normalized to picograms per cell.

\subsection{Measurement of extracellular carbonic anhydrase activity}

Carbonic anhydrase activity was assessed using the electrometric method (Gao et al., 2009). Cells were harvested by centrifugation at $4000 \mathrm{~g}$ for $5 \mathrm{~min}$ at $20^{\circ} \mathrm{C}$, washed once, and resuspended in $8 \mathrm{~mL} \mathrm{Na}$ barbital buffer $(20 \mathrm{mM}$, pH 8.2). A total of $5 \mathrm{~mL}$ of $\mathrm{CO}_{2}$-saturated icy distilled water was injected into the cell suspension, and the time required for a $\mathrm{pH}$ decrease from 8.2 to 7.2 at $4{ }^{\circ} \mathrm{C}$ was recorded. Extracellular carbonic anhydrase $\left(\mathrm{CA}_{\text {ext }}\right)$ activity was measured using intact cells. CA activity (E.U.) was calculated using the following formula: E.U. $=10 \times\left(T_{0} / T-1\right)$, where $T_{0}$ and $T$ represent the time required for the $\mathrm{pH}$ change in the absence or presence of the cells, respectively.

\subsection{Measurement of redox activity in the plasma membrane}

The redox activity of plasma membrane was assayed by monitoring the change in $\mathrm{K}_{3} \mathrm{FeCN}_{6}$ concentration that accompanied reduction of the ferricyanide to ferrocyanide. The ferricyanide $\mathrm{K}_{3} \mathrm{FeCN}_{6}$ cannot penetrate intact cells and has been used as an external electron acceptor (Nimer et al., 1998; Gao et al., 2018b). Stock solutions of $\mathrm{K}_{3} \mathrm{FeCN}_{6}$ were freshly prepared before use. A total of $5 \mathrm{~mL}$ of samples was taken after $2 \mathrm{~h}$ of incubation with $500 \mu \mathrm{mol} \mathrm{K}_{3} \mathrm{FeCN}_{6}$ and centrifuged at $4000 \mathrm{~g}$ for $10 \mathrm{~min}\left(20^{\circ} \mathrm{C}\right)$. The concentration of $\mathrm{K}_{3} \mathrm{FeCN}_{6}$ in the supernatant was measured spectrophotometrically at $420 \mathrm{~nm}$ (Shimadzu UV-1800, Kyoto, Japan). The decrease in $\mathrm{K}_{3} \mathrm{FeCN}_{6}$ during the $2 \mathrm{~h}$ of incubation was used to assess the rate of extracellular ferricyanide reduction that was presented as $\mu \mathrm{mol}\left(10^{6} \text { cells }\right)^{-1} \mathrm{~h}^{-1}$ (Nimer et al., 1998).

\subsection{Cell-driving pH drift experiment}

To obtain the $\mathrm{pH}$ compensation point, the cells were transferred to sealed glass vials containing a fresh medium (pH 8.2) with corresponding phosphate levels. The cell concentration for all treatments was $5.0 \times 10^{5} \mathrm{~mL}^{-1}$. The $\mathrm{pH}$ drift of the suspension was monitored at $20^{\circ} \mathrm{C}$ and a $200 \mu \mathrm{mol}$ photons $\mathrm{m}^{-2} \mathrm{~s}^{-1}$ light level. The $\mathrm{pH}$ compensation point was obtained when there was no further increase in $\mathrm{pH}$.

\subsection{Statistical analysis}

Results were expressed as means of replicates \pm standard deviation and data were analyzed using the software SPSS v.21. The data from each treatment conformed to a normal distribution (Shapiro-Wilk, $P>0.05$ ) and the variances could be considered equal (Levene's test, $P>0.05$ ). Twoway ANOVAs were conducted to assess the effects of $\mathrm{CO}_{2}$ and phosphate on net photosynthetic rate, dark respiration rate, ratio of net photosynthetic rate to dark respiration rate, rETR, Chl $a, K_{0.5}, \mathrm{CA}_{\text {ext }}$, reduction rate of ferricyanide, and $\mathrm{pH}$ compensation point. Least significant difference (LSD) was conducted for post hoc investigation. Repeated measurements of ANOVA were conducted to analyze the effects of DIC on net photosynthetic rate and the effect of incubation time on media $\mathrm{pH}$ in a closed system. Bonferroni was conducted for post hoc investigation as it is the best reliable post hoc test for repeated measurements of ANOVA (Ennos, 2007). The threshold value for determining statistical significance was $P<0.05$. 
Table 1. Two-way analysis of variance for the effects of $\mathrm{CO}_{2}$ and phosphate on net photosynthetic rate, dark respiration rate, and ratio of respiration to photosynthesis of $S$. costatum. $\mathrm{CO}_{2} *$ phosphate means the interactive effect of $\mathrm{CO}_{2}$ and phosphate, $\mathrm{d} f$ means degree of freedom, $F$ means the value of the $F$ statistic, and Sig. means the $p$ value.

\begin{tabular}{|c|c|c|c|c|c|c|c|c|c|}
\hline \multirow[b]{2}{*}{ Source } & \multicolumn{3}{|c|}{ Net photosynthetic rate } & \multicolumn{3}{|c|}{ Dark respiration rate } & \multicolumn{3}{|c|}{$\begin{array}{c}\text { Ratio of respiration } \\
\text { to photosynthesis }\end{array}$} \\
\hline & $\mathrm{d} f$ & $F$ & Sig. & $\mathrm{d} f$ & $F$ & Sig. & $\mathrm{d} f$ & $\mathrm{~F}$ & Sig. \\
\hline $\mathrm{CO}_{2}$ & 1 & 11.286 & 0.003 & 1 & 1.262 & 0.275 & 1 & 32.443 & $<0.001$ \\
\hline Phosphate & 4 & 157.925 & $<0.001$ & 4 & 169.050 & $<0.001$ & 4 & 7.081 & 0.001 \\
\hline $\mathrm{CO}_{2} *$ phosphate & 4 & 3.662 & 0.021 & 4 & 3.226 & 0.034 & 4 & 8.299 & $<0.001$ \\
\hline Error & 20 & & & 20 & & & 20 & & \\
\hline
\end{tabular}

\section{Results}

\subsection{Effects of $\mathrm{CO}_{2}$ and phosphate on photosynthetic and respiratory performances}

The net photosynthetic rate and dark respiration rate in $S$. costatum grown at various $\mathrm{CO}_{2}$ and phosphate concentrations were first investigated (Fig. 1). $\mathrm{CO}_{2}$ interacted with phosphate on net photosynthetic rate, with each factor having a main effect (Table 1 and Fig. 1a). Post hoc LSD comparison $(P=0.05)$ showed that $2.8 \mu \mathrm{mol}$ of $\mathrm{CO}_{2}$ reduced net photosynthetic rate when the phosphate level was below $4 \mu \mathrm{mol} \mathrm{L}^{-1}$ but did not affect it at the higher phosphate levels. Under the condition of $12.6 \mu \mathrm{mol}$ of $\mathrm{CO}_{2}$, net photosynthetic rate increased with phosphate level and reached the plateau (100.51 \pm $\left.9.59 \mu \mathrm{mol} \mathrm{O}{ }_{2}\left(10^{9} \text { cells }\right)^{-1} \mathrm{~h}^{-1}\right)$ at $1 \mu \mathrm{mol} \mathrm{L}^{-1}$ phosphate. Under the condition of $2.8 \mu \mathrm{mol}$ of $\mathrm{CO}_{2}$, net photosynthetic rate also increased with phosphate level but did not hit the peak $\left(101.46 \pm 9.19 \mu \mathrm{mol} \mathrm{O} \mathrm{O}_{2}\left(10^{9} \text { cells }\right)^{-1} \mathrm{~h}^{-1}\right)$ until $4 \mu \mathrm{mol} \mathrm{L}{ }^{-1}$ of phosphate. In terms of dark respiration rate (Fig. 1b), phosphate had a main effect on it and it interacted with $\mathrm{CO}_{2}$ (Table 1). Specifically, $2.8 \mu \mathrm{mol}$ of $\mathrm{CO}_{2}$ increased dark respiration rate at 0.05 and $0.25 \mu \mathrm{mol} \mathrm{L}^{-1}$ phosphate levels, but did not affect it when the phosphate level was above $1 \mu \mathrm{mol} \mathrm{L}{ }^{-1}$ (LSD, $P<0.05$ ). Regardless of $\mathrm{CO}_{2}$ level, respiration rate increased with phosphate availability and stopped at $1 \mu \mathrm{mol} \mathrm{L} \mathrm{L}^{-1}$.

The ratio of respiration to photosynthesis ranged from 0.23 to 0.40 (Fig. 1c). Both $\mathrm{CO}_{2}$ and phosphate had a main effect, and they interacted on the ratio of respiration to photosynthesis (Table 1). The level of $2.8 \mu \mathrm{mol}$ of $\mathrm{CO}_{2}$ increased the ratio when phosphate was lower than $4 \mu \mathrm{mol} \mathrm{L}^{-1}$ but did not affect it when phosphate levels were 4 or $10 \mu \mathrm{mol} \mathrm{L}^{-1}$.

Both $\mathrm{CO}_{2}$ and phosphate affected ETR and they also showed an interactive effect (Fig. 2 and Table 2). For instance, post hoc LSD comparison showed that $2.8 \mu \mathrm{mol}$ of $\mathrm{CO}_{2}$ did not affect ETR at lower phosphate levels $\left(0.05\right.$ and $\left.0.25 \mu \mathrm{mol} \mathrm{L}^{-1}\right)$ but increased it at higher phosphate levels $\left(1-10 \mu \mathrm{mol} \mathrm{L}^{-1}\right)$. Regardless of $\mathrm{CO}_{2}$ treatment, ETR increased with phosphate level $\left(0.05-4 \mu \mathrm{mol} \mathrm{L}^{-1}\right)$ but

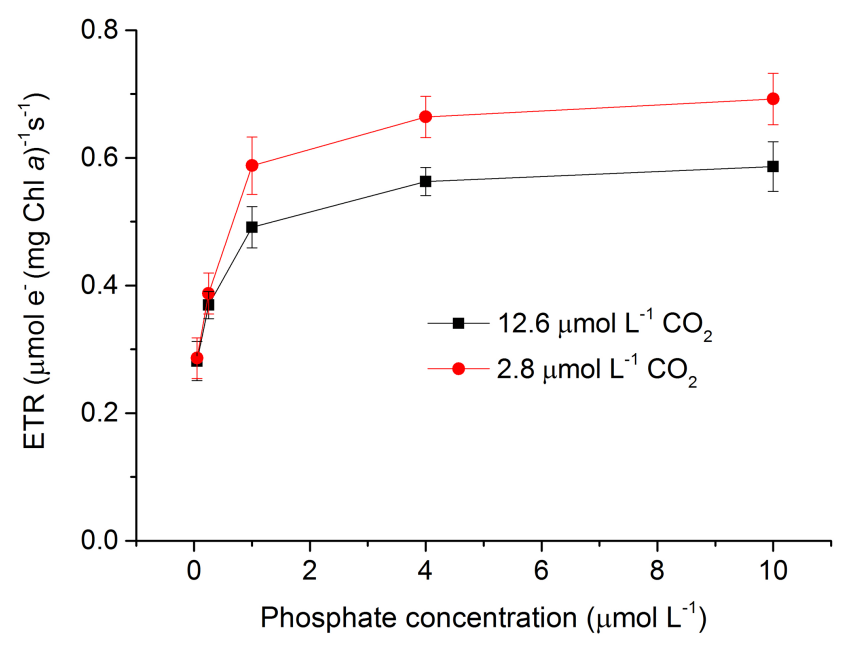

Figure 2. Relative electron transport rate (rETR) in S. costatum grown at various phosphate concentrations after 12.6 and $2.8 \mu \mathrm{mol} \mathrm{CO}_{2}$ treatments. The error bars indicate the standard deviations $(n=3)$.

the highest phosphate concentration did not result in a further increase in ETR (LSD, $P>0.05$ ).

The content of Chl $a$ was measured to investigate the effects of $\mathrm{CO}_{2}$ and phosphate on photosynthetic pigment in $S$. costatum (Fig. 3). Both $\mathrm{CO}_{2}$ and phosphate affected the synthesis of Chl $a$ and they had an interactive effect (Table 2). Post hoc LSD comparison $(P=0.05)$ showed that $2.8 \mu \mathrm{mol}$ of $\mathrm{CO}_{2}$ did not affect $\mathrm{Chl} a$ at 0.05 or $0.25 \mu \mathrm{mol} \mathrm{L}{ }^{-1}$ of phosphate but stimulated Chl $a$ synthesis at higher phosphate levels (1-10 $\left.\mu \mathrm{mol} \mathrm{L}^{-1}\right)$. Irrespective of $\mathrm{CO}_{2}$ treatment, Chl $a$ content increased with phosphate level and reached the plateau $\left(0.19 \pm 0.01 \mathrm{pg}\right.$ cell ${ }^{-1}$ for $12.6 \mu \mathrm{mol}$ of $\mathrm{CO}_{2}$ and $0.23 \pm 0.01 \mathrm{pg} \mathrm{cell}^{-1}$ for $2.8 \mu \mathrm{mol}$ of $\mathrm{CO}_{2}$ ) at $4 \mu \mathrm{mol} \mathrm{L}^{-1}$ of phosphate.

To assess the effects of $\mathrm{CO}_{2}$ and phosphate on photosynthetic $\mathrm{CO}_{2}$ affinity in $S$. costatum, the net photosynthetic rates of cell exposure to seven levels of DIC were measured (Fig. 4). After curve fitting, the values of $K_{0.5}$ for $\mathrm{CO}_{2}$ were calculated (Fig. 5). $\mathrm{CO}_{2}$ and phosphate interplayed on $K_{0.5}$ and each had a main effect (Table 2). The level 
Table 2. Two-way analysis of variance for the effects of $\mathrm{CO}_{2}$ and phosphate on relative electron transport rate (rETR), $\mathrm{Chl} a$, and $\mathrm{CO} 2$ level required to obtain half of the DIC-saturated maximum rate of photosynthetic $\mathrm{O}_{2}$ evolution $\left(K_{0.5}\right)$ of $S$. costatum. $\mathrm{CO}_{2} *$ phosphate means the interactive effect of $\mathrm{CO}_{2}$ and phosphate, $\mathrm{d} f$ means degree of freedom, $F$ means the value of the $F$ statistic, and Sig. means the $p$ value.

\begin{tabular}{|c|c|c|c|c|c|c|c|c|c|}
\hline \multirow[b]{2}{*}{ Source } & \multicolumn{3}{|c|}{ rETR } & \multicolumn{3}{|c|}{ Chl $a$} & \multicolumn{3}{|c|}{$K_{0.5}$} \\
\hline & $\mathrm{d} f$ & $F$ & Sig. & $\mathrm{d} f$ & $F$ & Sig. & $\mathrm{d} f$ & $F$ & Sig. \\
\hline $\mathrm{CO}_{2}$ & 1 & 28.717 & $<0.001$ & 1 & 32.963 & $<0.001$ & 1 & 96.182 & $<0.001$ \\
\hline Phosphate & 4 & 127.860 & $<0.001$ & 4 & 92.045 & $<0.001$ & 4 & 40.497 & $<0.001$ \\
\hline $\mathrm{CO}_{2} *$ phosphate & 4 & 3.296 & 0.031 & 4 & 3.871 & 0.017 & 4 & 3.821 & 0.018 \\
\hline Error & 20 & & & 20 & & & 20 & & \\
\hline
\end{tabular}

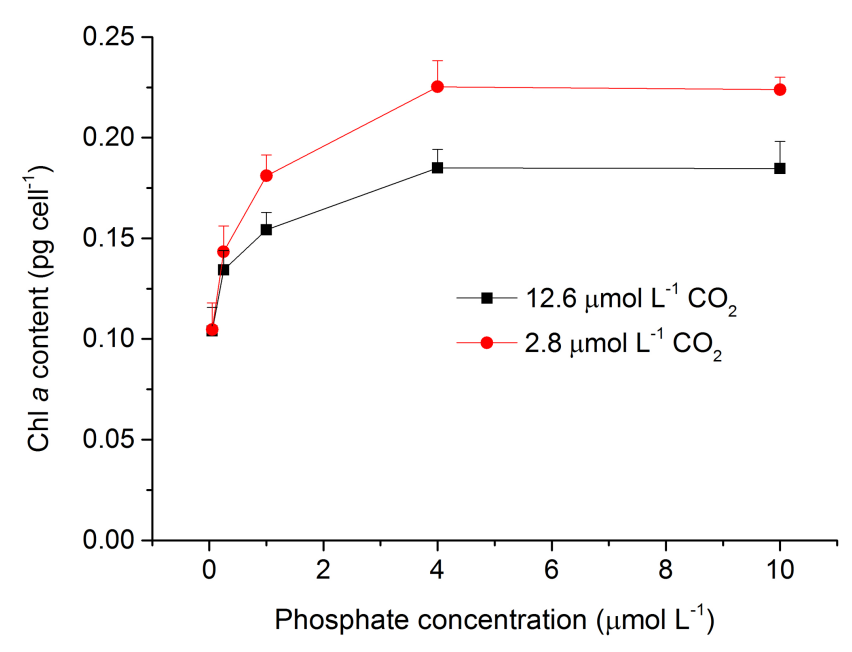

Figure 3. Photosynthetic $\mathrm{Chl} a$ content in $S$. costatum grown at various phosphate concentrations after 12.6 and $2.8 \mu \mathrm{mol} \mathrm{CO}_{2}$ treatments. The error bars indicate the standard deviations $(n=3)$.

of $2.8 \mu \mathrm{mol}$ of $\mathrm{CO}_{2}$ did not affect $K_{0.5}$ at the lowest phosphate level but reduced it at the other phosphate levels. Under the condition of $12.6 \mu \mathrm{mol}$ of $\mathrm{CO}_{2}$, higher phosphate levels $\left(0.25-4 \mu \mathrm{mol} \mathrm{L}^{-1}\right)$ reduced $K_{0.5}$ and the highest phosphate level led to a further decrease to $2.59 \pm 0.29 \mu \mathrm{mol} \mathrm{kg}^{-1}$ of seawater compared to the value of $4.00 \pm 0.30 \mu \mathrm{mol} \mathrm{kg}^{-1}$ of seawater at $0.05 \mu \mathrm{mol} \mathrm{L}-1$ of phosphate. The pattern with phosphate at $2.8 \mu \mathrm{mol}$ of $\mathrm{CO}_{2}$ was the same as $12.6 \mu \mathrm{mol}$ of $\mathrm{CO}_{2}$.

\subsection{The effects $\mathrm{CO}_{2}$ and phosphate on inorganic carbon acquisition}

To investigate the potential mechanisms that allow cells to overcome $\mathrm{CO}_{2}$ limitation during algal blooms, the activity of $\mathrm{CA}_{\mathrm{ext}}$, a CCM-related enzyme, was estimated under various $\mathrm{CO}_{2}$ and phosphate conditions (Fig. 6a). Both $\mathrm{CO}_{2}$ and phosphate had a main effect and they interacted on $\mathrm{CA}_{\mathrm{ext}}$ activity (Table 3$)$. Post hoc LSD comparison $(P=0.05)$ showed that $2.8 \mu \mathrm{mol}$ of $\mathrm{CO}_{2}$ induced more $\mathrm{CA}_{\text {ext }}$ activity under all phosphate conditions except for $0.05 \mu \mathrm{mol} \mathrm{L} \mathrm{L}^{-1}$ levels, compared to $12.6 \mu \mathrm{mol}$ of $\mathrm{CO}_{2}$. Under the condition of $12.6 \mu \mathrm{mol}$ of $\mathrm{CO}_{2}, \mathrm{CA}_{\text {ext }}$ activity increased $(0.04$
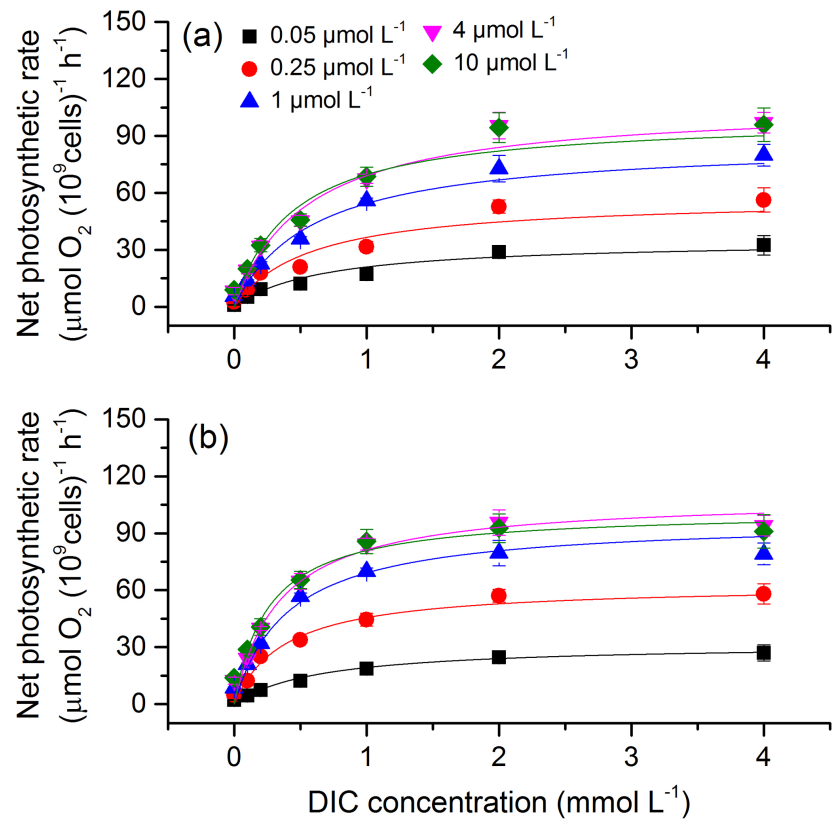

Figure 4. Net photosynthetic rate as a function of DIC for S. costatum grown at various phosphate concentrations after 12.6 (a) and $2.8 \mu \mathrm{mol} \mathrm{CO}_{2}$ (b) treatments. The error bars indicate the standard deviations $(n=3)$.

$\left.0.10 \mathrm{EU}\left(10^{6} \text { cells }\right)^{-1}\right)$ with phosphate level and stopped increasing at $1 \mu \mathrm{mol} \mathrm{L}{ }^{-1}$ of phosphate. Under the condition of $2.8 \mu \mathrm{mol}$ of $\mathrm{CO}_{2}, \mathrm{CA}_{\text {ext }}$ activity also increased (0.04-0.35 $\left.\mathrm{EU}\left(10^{6} \text { cells }\right)^{-1}\right)$ with phosphate level but reached the peak at $4 \mu \mathrm{mol} \mathrm{L}{ }^{-1}$ of phosphate. The redox activity of the plasma membrane was also assessed to investigate the factors that modulate $\mathrm{CA}_{\text {ext }}$ activity (Fig. $6 \mathrm{~b}$ ). The pattern of redox activity of the plasma membrane under various $\mathrm{CO}_{2}$ and phosphate conditions was the same as that of $\mathrm{CA}_{\mathrm{ext}}$ activity. That is, $\mathrm{CO}_{2}$ and phosphate had an interactive effect on redox activity of the plasma membrane, each having a main effect (Table 3).

To test cells' tolerance to high $\mathrm{pH}$ and obtain $\mathrm{pH}$ compensation points in $S$. costatum grown under various $\mathrm{CO}_{2}$ and phosphate levels, changes of media $\mathrm{pH}$ in a closed system were monitored (Fig. 7). The media pH under all phos- 


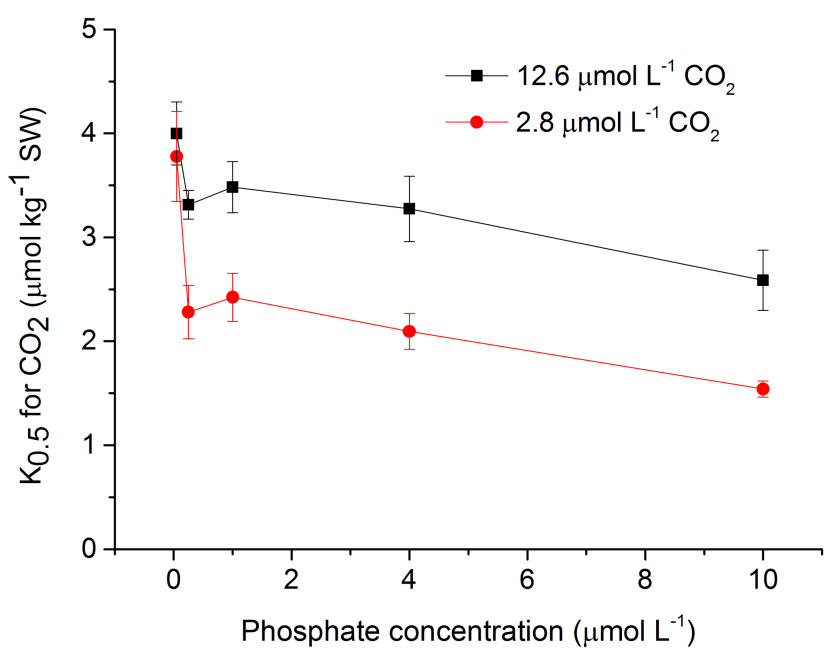

Figure 5. Half saturation constant $\left(K_{0.5}\right)$ for $\mathrm{CO}_{2}$ in $S$. costatum grown at various phosphate concentrations after 12.6 and $2.8 \mu \mathrm{mol} \mathrm{CO} 2$ treatments. The error bars indicate the standard deviations $(n=3)$.

phate conditions increased with incubation time (Table 4). Specifically speaking, there was a steep increase in $\mathrm{pH}$ during the first $3 \mathrm{~h}$; afterwards the increase became slower and it reached a plateau at $6 \mathrm{~h}$ (Bonferroni, $P<0.05$ ). Phosphate had an interactive effect with incubation time (Table 4). For instance, there was no significant difference in media $\mathrm{pH}$ among phosphate levels during the first $2 \mathrm{~h}$ of incubation but then divergence occurred and they stopped at different points. Two-way ANOVA showed that $\mathrm{CO}_{2}$ treatment did not affect $\mathrm{pH}$ compensation point but phosphate had a main effect (Table 3). Under each $\mathrm{CO}_{2}$ treatment, $\mathrm{pH}$ compensation point increased with phosphate level, with the lowest of $9.03 \pm 0.03$ at $0.05 \mu \mathrm{mol} \mathrm{L}^{-1}$ and highest of $9.36 \pm 0.04$ at $10 \mu \mathrm{mol} \mathrm{L}{ }^{-1}$ of phosphate.

\section{Discussion}

\subsection{Photosynthetic performances under various $\mathrm{CO}_{2}$ and phosphate conditions}

The lower $\mathrm{CO}_{2}$ availability reduced the net photosynthetic rate of $S$. costatum grown at the lower phosphate levels in the present study. However, Nimer et al. (1998) demonstrated that the increase in $\mathrm{pH}(8.3-9.5)$ did not reduce photosynthetic $\mathrm{CO}_{2}$ fixation of $S$. costatum and Chen and Gao (2004) reported that a higher $\mathrm{pH}(8.7)$ even stimulated the photosynthetic rate of $S$. costatum compared to the control ( $\mathrm{pH} 8.2$ ). The divergence between our and the previous studies may be due to different nutrient supply. Both Nimer et al. (1998) and Chen and Gao (2004) used f/2 media to grow algae. The phosphate concentration in $\mathrm{f} / 2$ media is $\sim 36 \mu \mathrm{mol} \mathrm{L}^{-1}$, which is replete for physiological activities in $S$. costatum.
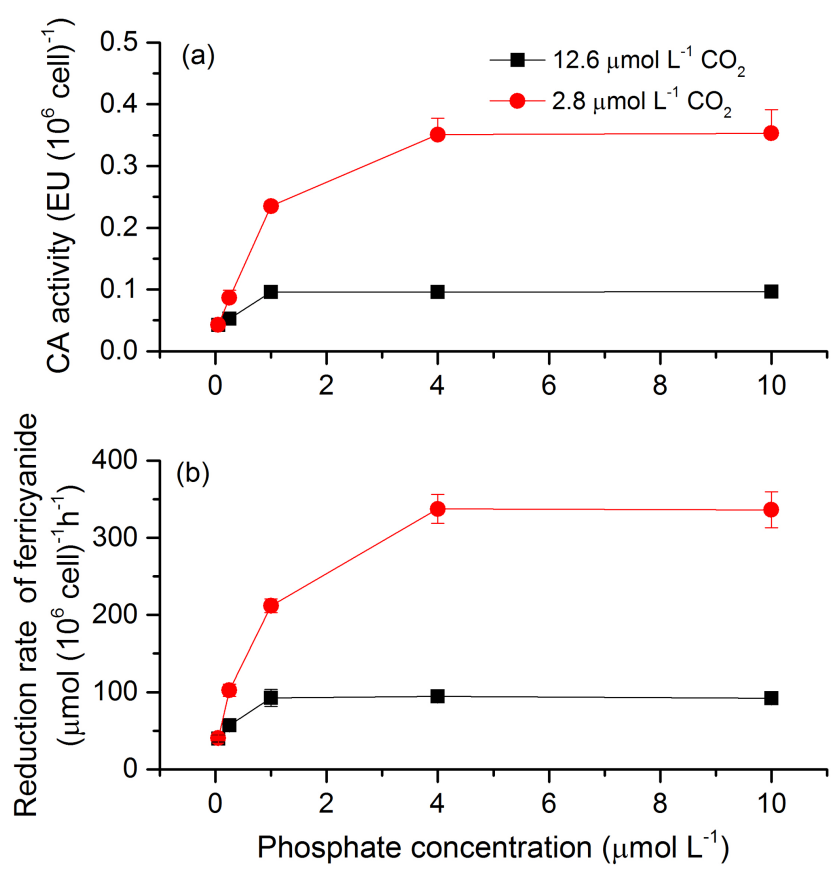

Figure 6. $\mathrm{CA}_{\text {ext }}$ activity (a) and reduction rate of ferricyanide (b) in $S$. costatum grown at various phosphate concentrations after 12.6 and $2.8 \mu \mathrm{mol} \mathrm{CO}_{2}$ treatments. The error bars indicate the standard deviations $(n=3)$.

Skeletonema costatum grown at higher phosphate levels (4 and $10 \mu \mathrm{mol} \mathrm{L}^{-1}$ ) also showed similar photosynthetic rates for the lower and higher $\mathrm{CO}_{2}$ treatments. Our finding combined with the previous studies indicates phosphorus plays an important role in dealing with low $\mathrm{CO}_{2}$ availability for photosynthesis in S. costatum.

Different from net photosynthetic rate, $2.8 \mu \mathrm{mol}$ of $\mathrm{CO}_{2}$ did not affect rETR at lower phosphate levels $(0.05$ and $\left.0.25 \mu \mathrm{mol} \mathrm{L}^{-1}\right)$ and stimulated it at higher phosphate levels $\left(1-10 \mu \mathrm{mol} \mathrm{L} \mathrm{L}^{-1}\right)$. This interactive effect of $\mathrm{CO}_{2}$ and phosphate may be due to their effects on Chl $a$. The level of $2.8 \mu \mathrm{mol} \mathrm{CO}_{2}$ induced more synthesis of $\mathrm{Chl} a$ at higher phosphate levels $\left(1-10 \mu \mathrm{mol} \mathrm{L}^{-1}\right)$. This induction of lower $\mathrm{CO}_{2}$ on photosynthetic pigment is also reported in green algae (Gao et al., 2016). More energy is required under lower $\mathrm{CO}_{2}$ to address the more severe $\mathrm{CO}_{2}$ limitation and thus more $\mathrm{Chl} a$ is synthesized to capture more light energy, particularly when phosphate was replete. Although P is not an integral component for chlorophyll, it plays an important role in cell energetics through high-energy phosphate bonds, i.e., ATP, which could support chlorophyll synthesis. The stimulating effect of $\mathrm{P}$ enrichment on photosynthetic pigment is also found in the green alga Dunaliella tertiolecta (Geider et al., 1998) and the brown alga Sargassum muticum (Xu et al., 2017). The increased photosynthetic pigment in $S$. costatum could partially explain the increased rETR and photosynthetic rate under the higher $\mathrm{P}$ conditions. 
Table 3. Two-way analysis of variance for the effects of $\mathrm{CO}_{2}$ and phosphate on $\mathrm{CA}_{\text {ext }}$ activity, redox activity of plasma membrane, and $\mathrm{pH}$ compensation point of $S$. costatum. $\mathrm{CO}_{2}$ * phosphate means the interactive effect of $\mathrm{CO}_{2}$ and phosphate, $\mathrm{d} f$ means degree of freedom, $F$ means the value of the $F$ statistic, and Sig. means the $p$ value.

\begin{tabular}{|c|c|c|c|c|c|c|c|c|c|}
\hline \multirow[b]{2}{*}{ Source } & \multicolumn{3}{|c|}{$\mathrm{CA}_{\text {ext }}$ activity } & \multicolumn{3}{|c|}{$\begin{array}{l}\text { Redox activity of } \\
\text { plasma membrane }\end{array}$} & \multicolumn{3}{|c|}{$\mathrm{pH}$ compensation point } \\
\hline & $\mathrm{d} f$ & $F$ & Sig. & $\mathrm{d} f$ & $F$ & Sig. & $\mathrm{d} f$ & $F$ & Sig. \\
\hline $\mathrm{CO}_{2}$ & 1 & 569.585 & $<0.001$ & 1 & 937.963 & $<0.001$ & 1 & 0.056 & 0.816 \\
\hline Phosphate & 4 & 176.392 & $<0.001$ & 4 & 276.362 & $<0.001$ & 4 & 226.196 & $<0.001$ \\
\hline $\mathrm{CO}_{2} *$ phosphate & 4 & 87.380 & $<0.001$ & 4 & 137.050 & $<0.001$ & 4 & 0.040 & 0.997 \\
\hline Error & 20 & & & 20 & & & 20 & & \\
\hline
\end{tabular}
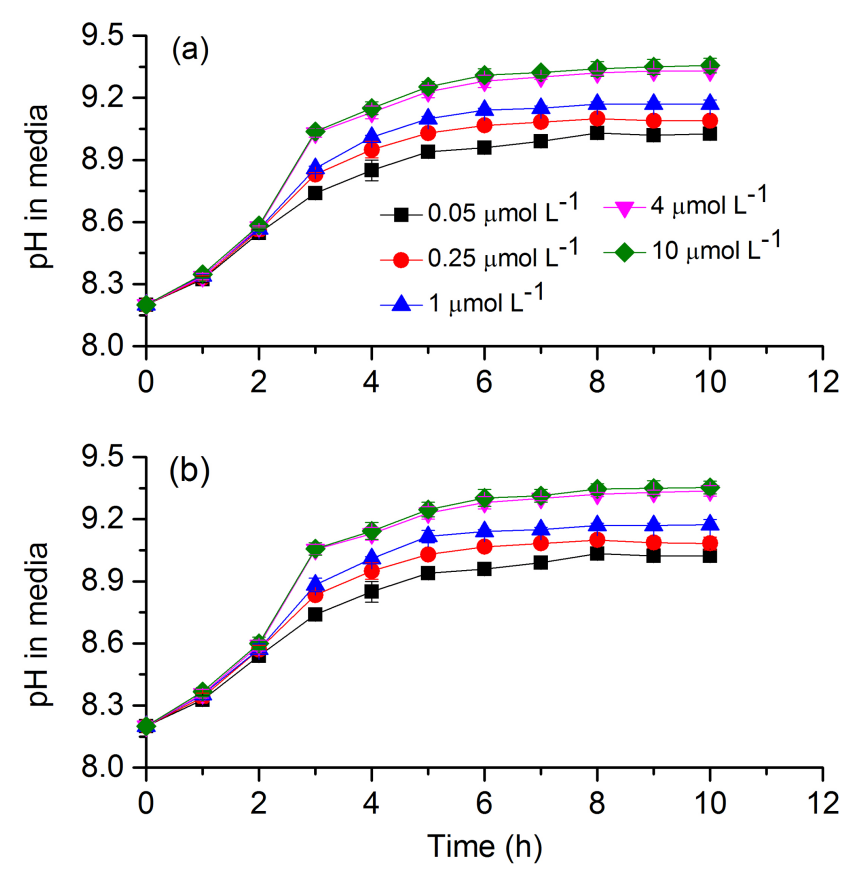

Figure 7. Changes of $\mathrm{pH}$ in a closed system caused by photosynthesis of $S$. costatum grown at various phosphate concentrations after 12.6 and $2.8 \mu \mathrm{mol} \mathrm{CO}_{2}$ treatments. The error bars indicate the standard deviations $(n=3)$.

\subsection{Ratio of respiration to photosynthesis}

The ratio of respiration to photosynthesis in algae indicates carbon balance in cells and carbon flux in marine ecosystems as well (Zou and Gao, 2013). The level of $2.8 \mu \mathrm{mol}$ of $\mathrm{CO}_{2}$ increased this ratio in $S$. costatum grown at the lower $\mathrm{P}$ conditions but did not affect it under the higher $\mathrm{P}$ conditions, indicating that $\mathrm{P}$ enrichment can offset the carbon loss caused by carbon limitation. To cope with $\mathrm{CO}_{2}$ limitation, cells might have to obtain energy from dark respiration under lower $\mathrm{P}$ conditions as it seems infeasible to acquire energy from the low ETR, which led to the increased dark respiration. However, $2.8 \mu \mathrm{mol}$ of $\mathrm{CO}_{2}$ induced higher ETR under P-replete conditions and energy used for inorganic carbon $\mathrm{CO}_{2}$ and
$\mathrm{HCO}_{3}^{-}$) acquisition could be from the increased ETR. Therefore, additional dark respiration was not triggered, avoiding carbon loss. Most studies regarding the effect of $\mathrm{CO}_{2}$ on ratio of respiration to photosynthesis focus on higher plants (Gifford, 1995; Ziska and Bunce, 1998; Cheng et al., 2010; Smith and Dukes, 2013); little is known about phytoplankton. Our study suggests that $\mathrm{CO}_{2}$ limitation may lead to carbon loss in phytoplankton but $\mathrm{P}$ enrichment could alter this trend, regulating carbon balance in phytoplankton and thus their capacity in carbon sequestration.

\subsection{Inorganic carbon acquisition under $\mathrm{CO}_{2}$ limitation and phosphate enrichment}

Decreased $\mathrm{CO}_{2}$ can usually induce higher inorganic carbon affinity in algae (Raven et al., 2012; Wu et al., 2012; Raven et al., 2017; Xu et al., 2017). In the present study, the lower $\mathrm{CO}_{2}$ did increase inorganic carbon affinity when the $\mathrm{P}$ level was higher than $0.25 \mu \mathrm{mol} \mathrm{L}^{-1}$ but did not affect it when $\mathrm{P}$ was $0.05 \mu \mathrm{mol} \mathrm{L} \mathrm{L}^{-1}$, indicating the important role of $\mathrm{P}$ in regulating cells' $\mathrm{CCMs}$ in response to environmental $\mathrm{CO}_{2}$ changes. The level of $2.8 \mu \mathrm{mol}$ of $\mathrm{CO}_{2}$ induced larger $\mathrm{CA}$ activity when $\mathrm{P}$ was above $0.25 \mu \mathrm{mol} \mathrm{L}^{-1}$ but did not increase it at $0.05 \mu \mathrm{mol} \mathrm{L}^{-1}$ of $\mathrm{P}$, which could explain the interactive effect of $\mathrm{P}$ and $\mathrm{CO}_{2}$ on inorganic carbon affinity as $\mathrm{CA}$ can accelerate the equilibrium between $\mathrm{HCO}_{3}^{-}$and $\mathrm{CO}_{2}$ and increase inorganic carbon affinity. Regardless of $\mathrm{CO}_{2}$, P enrichment alone increased CA activity and inorganic carbon affinity. $\mathrm{P}$ enrichment may stimulate the synthesis of CA by supplying required ATP. In addition, $P$ enrichment increased the redox activity of the plasma membrane in this study. It has been proposed that redox activity of the plasma membrane could induce extracellular CA activity via protonation extrusion of its active center (Nimer et al., 1998). Our result that the pattern of CA is exactly the same as that of redox activity of the plasma membrane shows a compelling correlation between CA and redox activity of the plasma membrane. The stimulating effect of $\mathrm{P}$ on redox activity of plasma membrane may be due to its effect on ETR. The increased ETR could generate excess reducing equivalents, particularly under $\mathrm{CO}_{2}$-limiting conditions. These excess reducing equiva- 
Table 4. Repeated measurements of analysis of variance for the effects of $\mathrm{CO}_{2}$ and phosphate on pH change during $10 \mathrm{~h}$ of incubation. Time $* \mathrm{CO}_{2}$ means the interactive effect of incubation time and $\mathrm{CO}_{2}$. Time*phosphate means the interactive effect of incubation time and phosphate. Time ${ }^{*} \mathrm{CO}_{2}{ }^{*}$ phosphate means the interactive effect of incubation time, $\mathrm{CO}_{2}$, and phosphate. $\mathrm{d} f$ means degree of freedom, $F$ means the value of the $F$ statistic, and Sig. means the $p$ value.

\begin{tabular}{lrrrrr}
\hline Source & Type III sum of squares & $\mathrm{d} f$ & Mean square & $F$ & Sig. \\
\hline Time & 40.766 & 10 & 4.077 & 8737.941 & $<0.001$ \\
Time* $\mathrm{CO}_{2}$ & 0.003 & 10 & $<0.001$ & 0.569 & 0.838 \\
Time*phosphate & 0.886 & 40 & 0.022 & 47.496 & $<0.001$ \\
Time* $\mathrm{CO}_{2} *$ phosphate & 0.002 & 40 & $<0.001$ & 0.112 & 1.000 \\
Error & 0.093 & 200 & $<0.001$ & & \\
\hline
\end{tabular}

lents would be transported from the chloroplast into the cytosol (Heber, 1974), supporting the redox chain in the plasma membrane (Rubinstein and Luster, 1993; Nimer et al., 1999) and triggering CA activity.

\subsection{Direct $\mathrm{HCO}_{3}^{-}$utilization due to phosphate enrichment}

A pH compensation point over 9.2 has been considered a sign of direct $\mathrm{HCO}_{3}^{-}$use for algae (Axelsson and Uusitalo, 1988) as the $\mathrm{CO}_{2}$ concentration is nearly zero at a $\mathrm{pH}$ above 9.2. This criterion has been justified based on experiments for both micro and macro-algae. For instance, the marine diatom Phaeodactylum tricornutum, with a strong capacity for direct $\mathrm{HCO}_{3}^{-}$utilization, has a higher $\mathrm{pH}$ compensation point of 10.3 (Chen et al., 2006). In contrast, the red macroalgae, Lomentaria articulata and Phycodrys rubens, that cannot utilize $\mathrm{HCO}_{3}^{-}$directly, and whose photosynthesis only depends on $\mathrm{CO}_{2}$ diffusion, have $\mathrm{pH}$ compensation points of less than 9.2 (Maberly, 1990). In terms of S. costatum, it has been reported to have a $\mathrm{pH}$ compensation point of 9.12, indicating a very weak capacity for direct $\mathrm{HCO}_{3}^{-}$utilization (Chen and Gao, 2004). Our study demonstrates that the $\mathrm{pH}$ compensation point of $S$. costatum varies with the availability of P. It is lower than 9.2 under P-limiting conditions but higher than 9.2 under P-replete conditions, suggesting that the capacity of direct $\mathrm{HCO}_{3}^{-}$utilization is regulated by $\mathrm{P}$ availability. Contrary to $\mathrm{CO}_{2}$ passive diffusion, the direct use of $\mathrm{HCO}_{3}^{-}$ depends on positive transport that requires energy (Hopkinson and Morel, 2011). P enrichment increased ETR in the present study and the ATP produced during the process of electron transport could be used to support $\mathrm{HCO}_{3}^{-}$positive transport. In addition, the increased respiration at higher $\mathrm{P}$ levels can also generate ATP to help $\mathrm{HCO}_{3}^{-}$positive transport. Our study indicates that $\mathrm{P}$ enrichment could trigger $\mathrm{HCO}_{3}^{-}$direct utilization and hence increase inorganic acquisition capacity of $S$. costatum to cope with $\mathrm{CO}_{2}$ limitation.

\subsection{CCMs and red tides}

In the development of red tides, the $\mathrm{pH}$ in seawater can be very high along with extremely low $\mathrm{CO}_{2}$ availability due to intensive photosynthesis (Hansen, 2002; Hinga, 2002). For instance, the $\mathrm{pH}$ level in the surface waters of the eutrophic Mariager Fjord, Denmark, is often above 9 during dinoflagellate blooms (Hansen, 2002). Diatoms are the causative species for red tides and $S$. costatum could outcompete other bloom algae (dinoflagellates Prorocentrum minimum and Alexandrium tamarense) under nutrient-replete conditions (Hu et al., 2011). However, the potential mechanisms are poorly understood. Our study demonstrates $S$. costatum has multiple CCMs to cope with $\mathrm{CO}_{2}$ limitation and the operation of CCMs is regulated by $\mathrm{P}$ availability. The CCMs of $S$. costatum are hampered under P-limiting conditions and only function when $\mathrm{P}$ is replete. This finding may explain why diatoms could overcome carbon limitation and dominate red tides when $\mathrm{P}$ is replete as well as the shift from diatoms to dinoflagellates when P is limiting (Mackey et al., 2012).

\section{Conclusions}

The present study investigated the role of $\mathrm{P}$ in regulating inorganic carbon acquisition and $\mathrm{CO}_{2}$ concentrating mechanisms in diatoms for the first time. The intensive photosynthesis and quick growth during algal blooms usually result in a noticeable increase in $\mathrm{pH}$ and decrease in $\mathrm{CO}_{2}$. Our study demonstrates that $\mathrm{P}$ enrichment could induce activity of extracellular carbonic anhydrase and direct utilization of $\mathrm{HCO}_{3}^{-}$in $S$. costatum to help overcome $\mathrm{CO}_{2}$ limitation, as well as increasing photosynthetic pigment content and rETR to provide required energy. This study provides important insight into the connection of phosphorus and carbon acquisition in diatoms and the mechanisms that help $S$. costatum dominate algal blooms.

Data availability. The underlying research data can be found in the Supplement.

Supplement. The supplement related to this article is available online at: https://doi.org/10.5194/bg-15-4871-2018-supplement. 
Author contributions. JX and GG designed the experiments, and GG, JY, JF, and XZ carried them out. GG prepared the paper with contributions from all co-authors.

Competing interests. The authors declare that they have no conflict of interest.

Acknowledgements. This work was supported by National Natural Science Foundation of China (nos. 41376156 \& 40976078), Natural Science Fund of Guangdong Province (no. S2012010009853), the China Postdoctoral Science Foundation (2018T110463 \& 2017M620270), Jiangsu Planned Projects for Postdoctoral Research Funds (1701003A), Science Foundation of Huaihai Institute of Technology (Z2016007), Foundation for High-level Talents in Higher Education of Guangdong, and Priority Academic Program Development of Jiangsu Higher Education Institutions.

Edited by: Clare Woulds

Reviewed by: Chris Hunt, Douglas Campbell, and one anonymous referee

\section{References}

Alderkamp, A. C., Kulk, G., Buma, A. G., Visser, R. J., Van Dijken, G. L., Mills, M. M., and Arrigo, K. R.: The effect of iron limitation on the photophysiology of Phaeocystis antarctica (Prymnesiophyceae) and Fragilariopsis cylindrus (Bacillariophyceae) under dynamic irradiance, J. Phycol., 48, 45-59, 2012.

Anderson, D. M., Burkholder, J. M., Cochlan, W. P., Glibert, P. M., Gobler, C. J., Heil, C. A., Kudela, R., Parsons, M. L., Rensel, J. E., and Townsend, D. W.: Harmful algal blooms and eutrophication: Examining linkages from selected coastal regions of the United States, Harmful Algae, 8, 39-53, 2008.

Axelsson, L. and Uusitalo, J.: Carbon acquisition strategies for marine macroalgae, Mar. Biol., 97, 295-300, 1988.

Barton, A. D., Irwin, A. J., Finkel, Z. V., and Stock, C. A.: Anthropogenic climate change drives shift and shuffle in North Atlantic phytoplankton communities, P. Natl. Acad. Sci. USA, 113, 2964-2969, 2016.

Beamud, S. G., Baffico, G. D., Reid, B., Torres, R., Gonzalez-Polo, M., Pedrozo, F., and Diaz, M.: Photosynthetic performance associated with phosphorus availability in mats of Didymosphenia geminata (Bacillariophyceae) from Patagonia (Argentina and Chile), Phycologia, 55, 118-125, 2016.

Beardall, J., Roberts, S., and Raven, J. A.: Regulation of inorganic carbon acquisition by phosphorus limitation in the green alga Chlorella emersonii, Can. J. Bot., 83, 859-864, 2005.

Berg, G. M., Glibert, P. M., Lomas, M. W., and Burford, M. A.: Organic nitrogen uptake and growth by the chrysophyte Aureococcus anophagefferens during a brown tide event, Mar. Biol., 129, 377-387, 1997.

Brembu, T., Mühlroth, A., Alipanah, L., and Bones, A. M.: The effects of phosphorus limitation on carbon metabolism in diatoms, Philos. T. R. Soc. B, 372, 20160406, https://doi.org/10.1098/rstb.2016.0406, 2017.
Bruland, K. W., Rue, E. L., and Smith, G. J.: Iron and macronutrients in California coastal upwelling regimes: implications for diatom blooms, Limnol. Oceanogr., 46, 1661-1674, 2001.

Caemmerer, S. V. and Farquhar, G. D.: Some relationships between the biochemistry of photosynthesis and the gas exchange of leaves, Planta, 153, 376-387, 1981.

Chen, X. and Gao, K.: Photosynthetic utilisation of inorganic carbon and its regulation in the marine diatom Skeletonema costatum, Funct. Plant Biol., 31, 1027-1033, 2004.

Chen, X., Qiu, C. E., and Shao, J. Z.: Evidence for $\mathrm{K}^{+}$-dependent $\mathrm{HCO}_{3}^{-}$utilization in the marine diatom Phaeodactylum tricornutum, Plant Physiol., 141, 731-736, 2006.

Cheng, W., Sims, D. A., Luo, Y., Coleman, J. S., and Johnson, D. W.: Photosynthesis, respiration, and net primary production of sunflower stands in ambient and elevated atmospheric $\mathrm{CO}_{2}$ concentrations: an invariant NPP : GPP ratio?, Glob. Change Biol., 6, 931-941, 2010.

Davies, A. G. and Sleep, J. A.: The photosynthetic response of nutrient-depleted dilute cultures of Skeletonema costatum to pulses of ammonium and nitrate; the importance of phosphate, J. Plankton Res., 11, 141-164, 1989.

Dickson, A. G.: Standard potential of the reaction: $\mathrm{AgCl}(\mathrm{s})+1 / 2 \mathrm{H}_{2}(\mathrm{~g})=\mathrm{Ag}(\mathrm{s})+\mathrm{HCl}(\mathrm{aq})$, and the standard acidity constant of the ion $\mathrm{HSO}_{4}^{-}$in synthetic sea water from 273.15 to 318.15 K, J. Chem. Thermodyn., 22, 113-127, 1990.

Dimier, C., Brunet, C., Geider, R., and Raven, J.: Growth and photoregulation dynamics of the picoeukaryote Pelagomonas calceolata in fluctuating light, Limnol. Oceanogr., 54, 823-836, 2009.

Ennos, R.: Statistical and Data Handling Skills in Biology, Pearson Education, Harlow, UK, 2007.

Falkowski, P.: Ocean Science: The power of plankton, Nature, 483, 17-20, 2012.

Field, C. B., Behrenfeld, M. J., Randerson, J. T., and Falkowski, P.: Primary production of the biosphere: integrating terrestrial and oceanic components, Science, 281, 237-240, 1998.

Gao, G., Gao, K., and Giordano, M.: Responses to solar UV radiation of the diatom Skeletonema costatum (Bacillariophyceae) grown at different $\mathrm{Zn}^{2+}$ concentrations, J. Phycol., 45, 119-129, 2009.

Gao, G., Liu, Y., Li, X., Feng, Z., and Xu, J.: An ocean acidification acclimatised green tide alga is robust to changes of seawater carbon chemistry but vulnerable to light stress, PLoS One, 11, e0169040, https://doi.org/10.1371/journal.pone.0169040, 2016.

Gao, G., Clare, A. S., Rose, C., and Caldwell, G. S.: Ulva rigida in the future ocean: potential for carbon capture, bioremediation, and biomethane production, GCB Bioenergy, 10, 39-51, 2018a.

Gao, G., Xia, J., Yu, J., and Zeng, X.: Physiological response of a red tide alga (Skeletonema costatum) to nitrate enrichment, with special reference to inorganic carbon acquisition, Mar. Environ. Res., 133, 15-23, 2018b.

Geider, R. J., Macintyre, H. L., Graziano, L. M., and McKay, R. M. L.: Responses of the photosynthetic apparatus of Dunaliella tertiolecta (Chlorophyceae) to nitrogen and phosphorus limitation, Eur. J. Phycol., 33, 315-332, 1998.

Gifford, R. M.: Whole plant respiration and photosynthesis of wheat under increased $\mathrm{CO}_{2}$ concentration and temperature: long-term vs. short-term distinctions for modelling, Glob. Change Biol., 1, 385-396, 1995. 
Hansen, P. J.: Effect of high pH on the growth and survival of marine phytoplankton: implications for species succession, Aquat. Microb. Ecol., 28, 279-288, 2002.

Heber, U.: Metabolite exchange between chloroplasts and cytoplasm, Ann. Rev. Plant Physio., 25, 393-421, 1974.

Hinga, K. R.: Effects of $\mathrm{pH}$ on coastal marine phytoplankton, Mar. Ecol. Prog. Ser., 238, 281-300, 2002.

Hopkinson, B. M. and Morel, F. M. M.: Efficiency of the $\mathrm{CO}_{2}$ concentrating mechanism of diatoms, P. Natl. Acad. Sci. USA, 108, 3830-3837, 2011.

Hopkinson, B. M., Dupont, C. L., and Matsuda, Y.: The physiology and genetics of $\mathrm{CO}_{2}$ concentrating mechanisms in model diatoms, Curr. Opin. Plant Biol., 31, 51-57, 2016.

$\mathrm{Hu}, \mathrm{H}$. and Zhou, Q.: Regulation of inorganic carbon acquisition by nitrogen and phosphorus levels in the Nannochloropsis sp., World J. Microb. Biot., 26, 957-961, 2010.

$\mathrm{Hu}, \mathrm{H}$., Zhang, J., and Chen, W.: Competition of bloom-forming marine phytoplankton at low nutrient concentrations, J. Environ. Sci-China, 23, 656-663, 2011.

Jeong, H. J., An, S. L., Franks, P. J. S., Lee, K. H., Ji, H. K., Kang, N. S., Lee, M. J., Jang, S. H., Lee, S. Y., and Yoon, E. Y.: A hierarchy of conceptual models of red-tide generation: Nutrition, behavior, and biological interactions, Harmful Algae, 47, 97-115, 2015.

Jiang, X., Han, Q., Gao, X., and Gao, G.: Conditions optimising on the yield of biomass, total lipid, and valuable fatty acids in two strains of Skeletonema menzelii, Food Chem., 194, 723-732, 2016.

Lefebvre, S., Mouget, J.-L., Loret, P., Rosa, P., and Tremblin, G.: Comparison between fluorimetry and oximetry techniques to measure photosynthesis in the diatom Skeletonema costatum cultivated under simulated seasonal conditions, J. Photoch. Photobio. B, 86, 131-139, 2007.

Li, G., Gao, K., Yuan, D., Zheng, Y., and Yang, G.: Relationship of photosynthetic carbon fixation with environmental changes in the Jiulong River estuary of the South China Sea, with special reference to the effects of solar UV radiation, Mar. Pollut. Bull., 62, 1852-1858, 2011.

Lin, S., Litaker, R. W., and Sunda, W. G.: Phosphorus physiological ecology and molecular mechanisms in marine phytoplankton, J. Phycol., 52, 10-36, 2016.

Liu, Y., Song, X., Cao, X., and Yu, Z.: Responses of photosynthetic characters of Skeletonema costatum to different nutrient conditions, J. Plankton Res., 35, 165-176, 2012.

Maberly, S. C.: Exogenous sources of inorganic carbon for photosynthesis by marine macroalgae, J. Phycol., 26, 439-449, 1990.

Mackey, K. R. M., Mioni, C. E., Ryan, J. P., and Paytan, A.: Phosphorus cycling in the red tide incubator region of Monterey Bay in response to upwelling, Front. Microbiol., 3, 33, https://doi.org/10.3389/fmicb.2012.00033, 2012.

Mccall, S. J., Hale, M. S., Smith, J. T., Read, D. S., and Bowes, M. J.: Impacts of phosphorus concentration and light intensity on river periphyton biomass and community structure, Hydrobiologia, 792, 315-330, 2017.

Moore, C. M., Mills, M. M., Arrigo, K. R., Bermanfrank, I., Bopp, L., Boyd, P. W., Galbraith, E. D., Geider, R. J., Guieu, C., and Jaccard, S. L.: Processes and patterns of oceanic nutrient limitation, Nat. Geosci., 6, 701-710, 2013.

Müller, S. and Mitrovic, S. M.: Phytoplankton co-limitation by nitrogen and phosphorus in a shallow reservoir: progressing from the phosphorus limitation paradigm, Hydrobiologia, 744, 255$269,2015$.

Nelson, D. M., Tréguer, P., Brzezinski, M. A., Leynaert, A., and Quéguiner, B.: Production and dissolution of biogenic silica in the ocean: Revised global estimates, comparison with regional data and relationship to biogenic sedimentation, Global Biogeochem. Сy., 9, 359-372, 1995.

Nimer, N. A., Ling, M. X., Brownlee, C., and Merrett, M. J.: Inorganic carbon limitation, exofacial carbonic anhydrase activity, and plasma membrane redox activity in marine phytoplankton species, J. Phycol., 35, 1200-1205, 1999.

Nimer, N. A., Warren, M., and Merrett, M. J.: The regulation of photosynthetic rate and activation of extracellular carbonic anhydrase under $\mathrm{CO}_{2}$-limiting conditions in the marine diatom Skeletonema costatum, Plant Cell Environ., 21, 805-812, 1998.

Pierrot, D., Lewis, E., and Wallace, D. W. R.: MS Excel program developed for $\mathrm{CO}_{2}$ system calculations, ORNL/CDIAC-105a, Carbon Dioxide Information Analysis Center, Oak Ridge National Laboratory, US Department of Energy, Oak Ridge, Tennessee, USA, 2006.

Raven, J. A., Giordano, M., Beardall, J., and Maberly, S. C.: Algal evolution in relation to atmospheric $\mathrm{CO}_{2}$ : carboxylases, carbonconcentrating mechanisms and carbon oxidation cycles, Philos. T. R. Soc. B, 367, 493-507, 2012.

Raven, J. A., Beardall, J., and Sánchez-Baracaldo, P.: The possible evolution, and future, of $\mathrm{CO}_{2}$-concentrating mechanisms, J. Exp. Bot., 68, 3701-3716, 2017.

Reed, M. L., Pinckney, J. L., Keppler, C. J., Brock, L. M., Hogan, S. B., and Greenfield, D. I.: The influence of nitrogen and phosphorus on phytoplankton growth and assemblage composition in four coastal, southeastern USA systems, Estuar. Coast. Shelf S., 177, 71-82, 2016.

Rost, B., Riebesell, U., Burkhardt, S., and Sültemeyer, D.: Carbon acquisition of bloom-forming marine phytoplankton, Limnol. Oceanogr., 48, 55-67, 2003.

Roy, R. N., Roy, L. N., Vogel, K. M., Porter-Moore, C., Pearson, T., Good, C. E., Millero, F. J., and Campbell, D. M.: The dissociation constants of carbonic acid in seawater at salinities 5 to 45 and temperatures 0 to $45^{\circ} \mathrm{C}$, Mar. Chem., 44, 249-267, 1993.

Rubinstein, B. and Luster, D. G.: Plasma membrane redox activity: components and role in plant processes, Annu. Rev. Plant Biol., 44, 131-155, 1993.

Smetacek, V. and Zingone, A.: Green and golden seaweed tides on the rise, Nature, 504, 84-88, 2013.

Smith, N. G. and Dukes, J. S.: Plant respiration and photosynthesis in global-scale models: incorporating acclimation to temperature and $\mathrm{CO}_{2}$, Glob. Change Biol., 19, 45-63, 2013.

Wang, J.: Phytoplankton communities in three distinct ecotypes of the Changjiang estuary, J. Ocean U. China, 32, 422-428, 2002.

Wu, X., Gao, G., Giordano, M., and Gao, K.: Growth and photosynthesis of a diatom grown under elevated $\mathrm{CO}_{2}$ in the presence of solar UV radiation, Fund. Appl. Limnol., 180, 279-290, 2012.

Xu, Z., Gao, G., Xu, J., and Wu, H.: Physiological response of a golden tide alga (Sargassum muticum) to the interaction of ocean acidification and phosphorus enrichment, Biogeosciences, 14, 671-681, https://doi.org/10.5194/bg-14-671-2017, 2017.

Young, J. N. and Morel, F. M. M.: Biological oceanography: The $\mathrm{CO}_{2}$ switch in diatoms, Nat. Clim. Change, 5, 722-723, 2015. 
Ziska, L. H. and Bunce, J. A.: The influence of increasing growth temperature and $\mathrm{CO}_{2}$ concentration on the ratio of respiration to photosynthesis in soybean seedlings, Glob. Change Biol., 4, 637-643, 1998.
Zou, D. and Gao, K.: Thermal acclimation of respiration and photosynthesis in the marine macroalga Gracilaria lemaneiformis (Gracilariales, Rhodophyta), J. Phycol., 49, 61-68, 2013. 